\section{Classification and Inheritance of Morphological and Agronomic Characteristics in Kentucky Bluegrass (Poa pratensis L.)}

\author{
Robert R. Shortell ${ }^{1}$, William A. Meyer, and Stacy A. Bonos \\ Department of Plant Biology and Pathology, Rutgers, The State University of \\ New Jersey, 59 Dudley Road, New Brunswick, NJ 08901
}

Additional index words. heritability, growth habit, spaced-plants

\begin{abstract}
The apomictic breeding behavior of Kentucky bluegrass (Poa pratensis L.) results in many unique cultivars. A classification system was previously developed to characterize the large number of Kentucky bluegrass cultivars into different types. However, many new cultivars have been released since the last refinement of the classification system. The objectives of this study were to determine differences in morphological and agronomic characteristics among select Kentucky bluegrass cultivars representing the major classification types and to determine broad-sense heritability estimates for important morphological (plant height, panicle length, flag leaf height, and flag leaf length and width) and agronomic (rhizome spread) traits in Kentucky bluegrass. A spaced-plant nursery trial was established in the spring of 2003 at Adelphia, NJ. One hundred seventy-three cultivars and selections were planted in a randomized complete block design with three replications. The morphological and agronomic traits listed were measured on spaced plants. High Density type cultivars (formerly the Aggressive type cultivars) had the most prostrate growth habit with plant heights of 33 and $43 \mathrm{~cm}$ in 2004 and 2005, respectively. Mid-Atlantic and Texas $\times$ Kentucky bluegrass hybrids had the widest rhizome spread (Mid-Atlantic $=73$ and $121 \mathrm{~cm}$; Texas $\times$ Kentucky bluegrass hybrids $=72$ and $122 \mathrm{~cm}$ ) in 2004 and 2005, respectively. Broad-sense heritability estimates were high for plant height $(\mathrm{H}=\mathbf{0 . 8 4})$, panicle length $(\mathrm{H}=\mathbf{0 . 8 8})$, flag leaf height $(H=0.85)$, and rhizome spread $(H=0.85)$; moderate for flag leaf length $(H=0.71)$; and low for flag leaf width $(\mathrm{H}=\mathbf{0 . 1 1})$. This study characterizes new cultivars into respective groups and identifies the genetic inheritance of important morphological and agronomic traits in Kentucky bluegrass.
\end{abstract}

Kentucky bluegrass (Poa pratensis L.) is a perennial turfgrass species that is widely adapted to many distinct environments. The extensive rhizome system of Kentucky bluegrass gives it the ability to tolerate and recover from many environmental stresses more quickly than bunch-type species (Bonos and Murphy, 1999; Meyer and Funk, 1989).

Kentucky bluegrass reproduces through an asexual process called apomixis. Apomixis allows for the development of trueto-type seed from the maternal plant (Bashaw and Funk, 1987; Funk, 2000; Turgeon, 1999). It reduces outcrossing, which serves to prevent recombination and fix hybrid vigor (Bicknell and Koltunow, 2004). This results in many unique genotypes of Kentucky bluegrass. This is beneficial because once superior genotypes are identified, they can be preserved through apomixis and produce uniform, stable cultivars (Bashaw and Funk, 1987; Funk, 2000).

Received for publication 29 Oct. 2008. Accepted for publication 18 Dec. 2008.

New Jersey Experiment Station Publication Number D-12180-08-08.

${ }^{1}$ To whom reprint requests should be addressed; e-mail shortell@eden.rutgers.edu.

system was developed to characterize the similarities and differences between cultivars and as a guide to help turfgrass managers increase diversity and uniformity when developing blends of Kentucky bluegrass. The description of the classification types has been previously reported (Bonos et al., 2000; Murphy et al., 1997). Many new Kentucky bluegrasses have been developed since the previous classification based on spaced plants was completed and other older cultivars have been discontinued (Bonos, 2007; Bonos et al., 2000). Therefore, we felt it was important to characterize recently developed Kentucky bluegrass cultivars that are or will become commercially available.

Morphological and agronomic characteristics are used by breeders in the development of improved cultivars and by managers for specific cultivar selection. Plant height and rhizome spread are useful characteristics because a low-growing, aggressive spreading cultivar should be able to tolerate lower heights of cut, recover quickly, and fill in damaged areas (Meyer and Funk, 1989). Leaf texture (measured here as leaf width) is also an important characteristic used in the development of new turfgrass cultivars. Fine leaf texture is typically correlated with higher shoot density in mowed turf situations (Bashaw and Funk, 1987; Turgeon, 1999). Turfgrass breeders have been selecting for higher shoot density for decades (Meyer and Funk, 1989) because it results in improved turf quality and better weed competition.

Because these traits are widely used to predict cultivar performance in a number of different environments, it would be helpful to turfgrass breeders to know the heritability of these morphological traits in Kentucky bluegrass. Broad-sense heritability estimates the total genetic effects influencing a trait and includes additive, dominance, and epistatic effects (Nyquist, 1991; Poehlman and Sleper, 1995). In crosspollinated species, narrowsense heritability is typically more useful to plant breeders because it measures the additive gene effects, which are passed on to the progeny more predictably than dominant or epistatic gene effects (Poehlman and Sleper, 1995). However, when working with apomictic or asexually propagated crops, in which hybrid vigor and both additive and nonadditive gene action are fixed, estimates of broad-sense heritability are more appropriate (Poehlman and Sleper, 1995). This technique has been used by Berry et al. (1969) to calculate heritability of several agronomic traits in Kentucky bluegrass. Heritability partitions the phenotypic variation into genetic and environmental components so that the effect of the environment on a specific trait can be determined. Characters with low heritability are typically highly affected by the environment, and characters with high heritability are less affected by the environment. Therefore, characters with high heritability have little environmental influence and should be consistent in multiple environments.

\section{Materials and Methods}

One hundred seventy-three Kentucky bluegrass cultivars and selections were evaluated in this study (Table 1). These cultivars and selections represented all of the entries included in the 2000 National Kentucky bluegrass test sponsored by the National Turfgrass Evaluation Program (Morris, 2000). Single seedlings were transplanted into 48 -cell flats $(90 \mathrm{~cm} \times 45 \mathrm{~cm})$ and allowed to establish in the greenhouse. The plants were screened for apomixis in the greenhouse and all off-types were discarded. The plants were then established in a spaced-plant nursery at the Rutgers University Plant Biology and Pathology Research and Extension Farm in Adelphia, NJ, in April 2003 on a welldrained Freehold sandy loam (fine-loamy, mixed, mesic, Typic Hapludult). The experiment was established in a randomized complete block design with three replications. Four plants of each entry were planted per replicate for a total of 12 plants per entry. The 
Table 1. Kentucky bluegrass (Poa pratensis L.) cultivars and selections evaluated in a spaced-plant nursery established in May 2003.

\begin{tabular}{|c|c|}
\hline Classification type & Cultivar or selection \\
\hline High Density & HV $140^{z}$, Limousine, Julius, North Star, Bariris \\
\hline BVMG & Baron, Envicta, Goldrush, Abbey, Raven, Marquis \\
\hline Common & Wellington, Kenblue \\
\hline Compact & 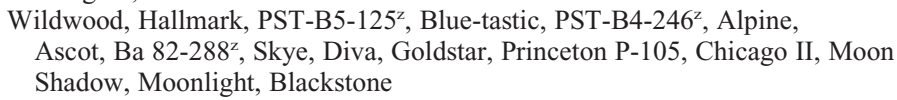 \\
\hline Compact-America & 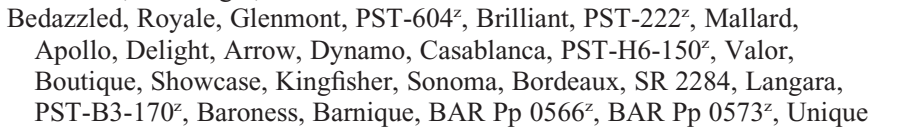 \\
\hline Compact-Midnight & $\begin{array}{l}\text { Midnight, Midnight II, Quantum Leap, Arcadia, Unknown, Impact, Total } \\
\text { Eclipse, Odyssey, NuGlade, Perfection, Tsunami, Ginney, Courtyard, } \\
\text { Alexa, J-2885, Blue Velvet, Everest, Awesome, Excursion, Freedom III, } \\
\text { EverGlade, Nu Destiny, Barrister, Beyond, Rugby II, Award, } \\
\text { Freedom II, Liberator, Bluestone }\end{array}$ \\
\hline CELA & Jefferson ${ }^{y}$ \\
\hline Julia & Avalanche, Pick $453^{z}$, Rampart, H92-558 \\
\hline Mid-Atlantic & Eagleton, PST-161², Cabernet, Appalachian \\
\hline Shamrock & $\begin{array}{l}\text { Shamrock, Lakeshore, Moonshine, Katie, Brooklawn, Champagne, } \\
\text { Durham, Mongoose, A98-1028 } \text {, Champlain }\end{array}$ \\
\hline $\begin{array}{l}\text { Texas } \times \text { Kentucky } \\
\text { bluegrass hybrid }\end{array}$ & Thermal Blue, Longhorn \\
\hline Other & 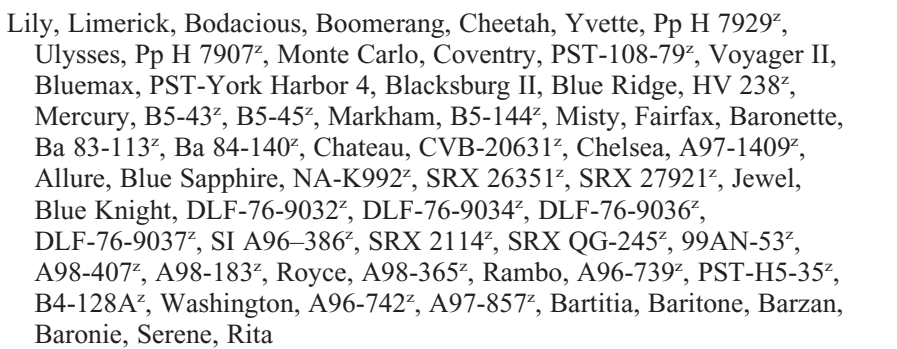 \\
\hline
\end{tabular}

${ }^{2}$ Denotes experimental selection.

y Not included in principal component analysis or Table 3 as a result of the limited number of cultivars.

field received $98 \mathrm{~kg} \cdot \mathrm{ha}^{-1} /$ year $\mathrm{N}$ using a 3.5 4.4-8.3 fertilizer (elemental nitrogen, phosphorus, and potassium, respectively) applied half in the spring and half in the fall. The field was mowed at a height of $20 \mathrm{~cm}$ twice per year, once after seed maturity and once before the onset of winter. Labeled pre(DCPA and dithiopyr) and postemergence (dicamba and halosulfuron) herbicides were used to control broadleaf weeds, sedges, and $P$. annua. The field was not irrigated and no severe disease outbreaks were observed.

The agronomic and morphological characteristics were measured on spaced plants in 2004 and 2005 following the experimental methods required for Plant Variety Protection (PVP) applications (USDA, 2005). Plant morphological measurements (plant height, panicle length, flag leaf height, width, and length) were taken $\approx 2$ weeks after anthesis, when all plant panicles were fully expanded (late-May to mid-July in both years). Plant height was measured from the soil surface to the average height of the majority of the panicles. Rhizome spread was measured, after mowing, in two directions perpendicular to each other and represented the longest extending rhizomes in those two directions. Rhizome spread measurements were used to characterize cultivars and selections that have been described as having extensive, spreading rhizome systems. Rhizome spread and plant height were taken on an individual plant basis with each plant receiving one observation per plant. Data were collected on each of the four plants per replicate and averaged to obtain one value per replication. Panicle length, flag leaf height, and width and length measurements were calculated as the average of three separate flowering culms from each of the four plants per replicate. Panicle length was measured from the bottom node to the tip of the longest panicle. Flag leaf height was measured as the distance between the soil surface and the collar of the flag leaf. Flag leaf blade width was measured at the widest point on the flag leaf. Flag leaf blade length was measured from the collar to the tip of the blade. Flag leaf length and width measurements were used to characterize those types with distinct leaf texture differences such as narrow leaf blades. As a result of the large number of entries and the hot temperatures of late spring/early summer, plants were measured in order of maturity; which helped to minimize differences in the plant's response to desiccation caused by seed maturity.

\section{Statistical analysis}

Means separation of types. To determine differences in morphological and agronomic characteristics between the Kentucky bluegrass classification types, data from cultivars and selections within types were combined and subjected to analysis of variance. Means were separated using Fisher's protected least significant difference at the $0.05 P$ level
(Table 2). As a result of space restrictions, the data on individual cultivar responses were not included in this article. It was previously reported by Shortell et al. (2006).

Broad-sense heritability. All characteristics were subjected to analysis of variance to determine broad-sense heritability estimates on an entry-mean basis. Broad-sense heritability estimates were determined from restricted maximum likelihood variance and covariance components using the random model of Proc MIXED (Bonos et al., 2004) (SAS Institute, Cary, NC). Ninety-five percent confidence intervals for heritability estimates were determined according to Steel et al. (1997). This technique (or a variation thereof) has previously been used to calculate broad-sense heritability from clonally replicated turfgrass plants (Berry et al., 1969; Bonos et al., 2003; Burton and DeVane, 1953).

Principal component analysis. The relationships between cultivars and selections based on all morphological characteristics were tested using multivariate principal component analysis PROC PRINCOM (SAS Institute, Cary, NC) as used by Bonos et al. (2000) (Figs. 1 and 2). One hundred seventy-three cultivars and selections and seven morphological variables were included in the data set analyzed. However, the addition of the "Other" group of cultivars (66 cultivars or selections that possess characteristics intermediate between the two groups) in the principal component analysis graph made it difficult to see relationships between cultivars and selections within the major groups Therefore, cultivars and selections in the "Other" group were omitted from the principal component analysis graph (Figs. 1 and 2; Table 1)

\section{Results and Discussion}

Significant differences between types were observed for all morphological measurements except flag leaf length and width in both years of the study (Table 2). Measurements in both 2004 and 2005, under spaced-plant conditions, indicated that the High Density (formerly Aggressive type), BVMG, and Compact (including Compact-Midnight and Compact-America) type cultivars evaluated in this study had the shortest plant heights. Common type cultivars and selections were the tallest entries in both years of the study. This is consistent with previous research (Bonos et al., 2000; Burt and Christians, 1990; Ebdon et al., 1998). Mid-Atlantic type and Texas $\times$ Kentucky bluegrass hybrids were intermediate in height. Compact and Compact-Midnight type entries had similar morphological traits in both years. Compact-America type cultivars and selections exhibited similar morphological traits as the BVMG types.

High broad-sense heritability estimates were observed for traits affecting plant stature [plant height: $\mathrm{H}=0.84$; panicle length: $\mathrm{H}=0.88$; and flag leaf height: $\mathrm{H}=0.85$ (Table $3)]$. High heritability estimates have also been observed for plant height measurements in 
Table 2. Morphological and agronomic characteristics of Kentucky bluegrass classification types established in a field trial in May 2003.

\begin{tabular}{|c|c|c|c|c|c|c|c|c|c|c|c|c|}
\hline & \multicolumn{2}{|c|}{ Plant ht } & \multicolumn{2}{|c|}{ Panicle length } & \multicolumn{2}{|c|}{ Flag leaf ht } & \multicolumn{2}{|c|}{ Rhizome spread } & \multicolumn{2}{|c|}{ Flag leaf length } & \multicolumn{2}{|c|}{ Flag leaf width } \\
\hline & 2004 & 2005 & 2004 & 2005 & 2004 & 2005 & 2004 & 2005 & 2004 & 2005 & 2004 & 2005 \\
\hline Type & -- & & 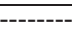 & 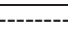 & & & 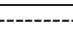 & 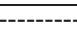 & & 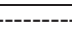 & & \\
\hline Common & 69 & 71 & 8 & 9 & 36 & 45 & 65 & 116 & 0.27 & 0.31 & 4.1 & 3.4 \\
\hline Julia & 46 & 67 & 8 & 9 & 27 & 39 & 61 & 102 & 0.40 & 0.32 & 3.7 & 2.6 \\
\hline Mid-Atlantic & 50 & 61 & 9 & 10 & 26 & 34 & 73 & 121 & 0.34 & 0.31 & 4.2 & 3.5 \\
\hline Shamrock & 50 & 58 & 8 & 8 & 26 & 32 & 69 & 120 & 0.35 & 0.30 & 3.8 & 2.8 \\
\hline Other & 45 & 55 & 8 & 8 & 24 & 32 & 58 & 101 & 0.33 & 0.29 & 3.7 & 3.1 \\
\hline TB $\times$ KB Hybrids ${ }^{z}$ & 51 & 53 & 8 & 8 & 34 & 39 & 72 & 122 & 0.35 & 0.33 & 5.1 & 3.6 \\
\hline Compact & 47 & 53 & 8 & 8 & 25 & 29 & 62 & 108 & 0.31 & 0.28 & 3.7 & 3.0 \\
\hline BVMG & 40 & 51 & 7 & 8 & 21 & 30 & 64 & 103 & 0.37 & 0.31 & 3.5 & 3.3 \\
\hline Compact-Midnight & 43 & 50 & 8 & 8 & 23 & 29 & 60 & 101 & 0.31 & 0.28 & 4.1 & 3.3 \\
\hline Compact-America & 38 & 47 & 7 & 7 & 23 & 30 & 47 & 79 & 0.31 & 0.29 & 4.2 & 3.3 \\
\hline High Density & 33 & 43 & 5 & 6 & 15 & 23 & 47 & 74 & 0.31 & 0.26 & 3.1 & 2.5 \\
\hline $\begin{array}{c}\text { Least significant } \\
\text { difference }_{0.05}\end{array}$ & 5 & 6 & 1 & 2 & 3 & 5 & 8 & 6 & NS & NS & NS & NS \\
\hline $\mathrm{CV} \% 0^{\mathrm{y}}$ & 22 & 24 & 17 & 19 & 20 & 21 & 23 & 24 & NS & NS & NS & NS \\
\hline
\end{tabular}

${ }^{\mathrm{z}}$ Texas $\times$ Kentucky bluegrass hybrids.

${ }^{\mathrm{y}} \mathrm{The}^{\mathrm{cv}}$ presented is the total ${ }^{\mathrm{cv}}$ for the analysis of variance.

$\mathrm{NS}=$ nonsignificant.

\section{Principal Component Analysis Year 1, 2004}

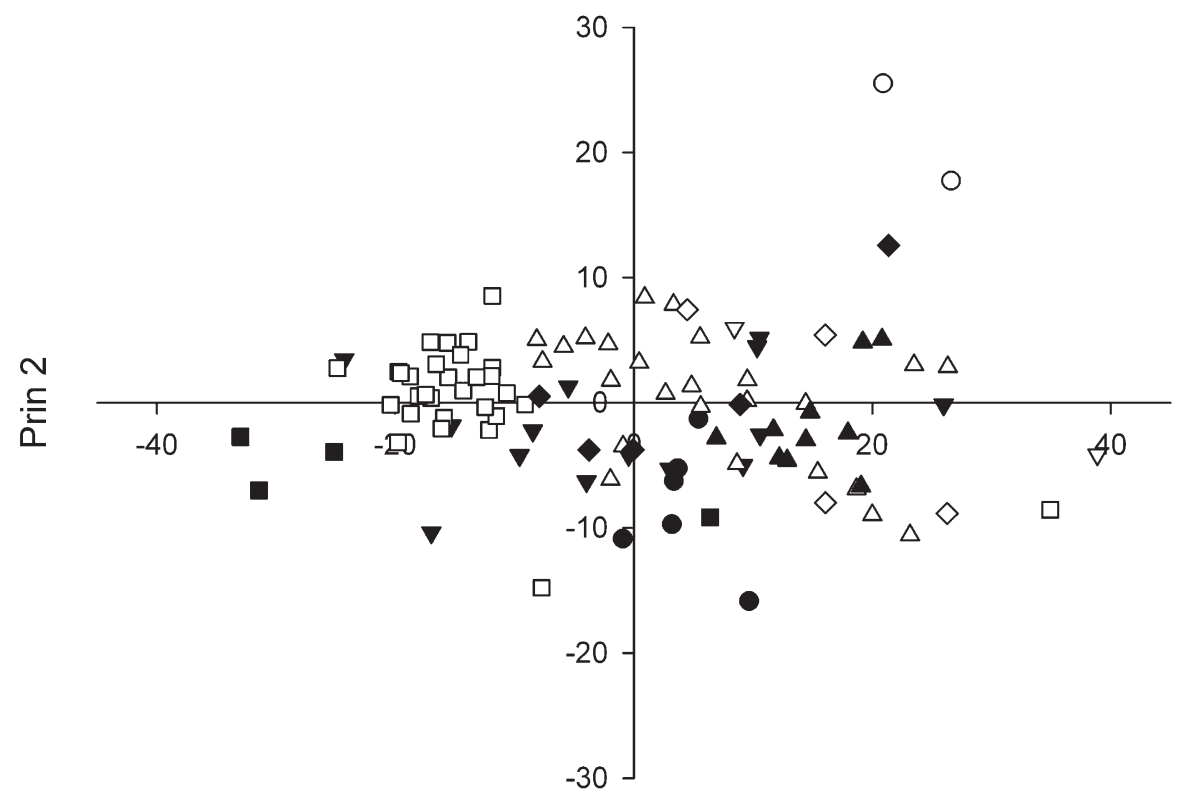

Prin 1

\begin{tabular}{|ll|}
\hline & BVMG \\
\hline & Common \\
$\nabla$ & Compact \\
$\Delta$ & Compact America \\
$\square$ & High Density \\
$\square$ & Compact Midnight \\
$\diamond$ & Julia \\
$\diamond$ & Mid-Atlantic \\
$\Delta$ & Shamrock \\
$\nabla$ & Texas \\
\hline
\end{tabular}

Fig. 1. Principal component analysis (PCA) of Kentucky bluegrass cultivars and selections based on morphological characteristics in 2004. PC1 accounted for $68.7 \%$ of the variation and was strongly influenced by rhizome spread. PC2 accounted for $22.5 \%$ of the variation and was strongly influenced by plant height.
Kentucky bluegrass (Pepin and Funk, 1974) and maize (Zea mays L.) (Soleri and Smith, 2002).

Low growth habit is a trait often selected for turfgrass breeding (Meyer and Funk, 1989). Plants with lower growth habits can typically tolerate closer mowing as a result of the lower placement of the crown relative to the soil surface and the slower rate of leaf elongation (Meyer and Funk, 1989; Turgeon, 1999). The high broad-sense heritability estimates observed for these traits indicate that they are under strong genetic control and not strongly affected by the environment. This indicates that selected plants should maintain a low growth habit across differing environments.

Rhizome spread is an indication of rhizome elongation and vigorous lateral growth. This is a beneficial characteristic in Kentucky bluegrass because plants with more lateral spread should be able to recover more quickly from stresses, including mowing or traffic. Mid-Atlantic type cultivars, Texas $\times$ Kentucky bluegrass hybrids, and Common type cultivars exhibited the most extensive rhizome spread (Table 2). This is a defining attribute of these types (Bonos et al., 2000; Murphy et al., 1997; Shortell et al., 2005), so it is not surprising that they exhibited the farthest spreading capability. Cultivars within the High Density and Compact-America types exhibited the shortest rhizome spread (Table 2) when evaluated as spaced plants.

The results for the High Density (formerly Aggressive) type cultivars are somewhat contradictory because this type exhibited aggressive rhizome growth in a previous study (Bonos et al., 2000). However, the only cultivar replicated in both trials was 'Limousine' and when grown as a spaced-plant in New Jersey, Limousine is very decumbent and slow-growing (personal observation). Previous studies have suggested that this type may dominate blends or mixtures at lawn-type cutting heights (Bonos et al., 2000; Murphy et al., 1997, Park et al., 2005). However, at fairway cutting heights, this group did not exhibit improved wear tolerance (Park et al., 2005; Shortell et al., 2005), which would be 


\section{Principal Component Analysis Year 2, 2005}

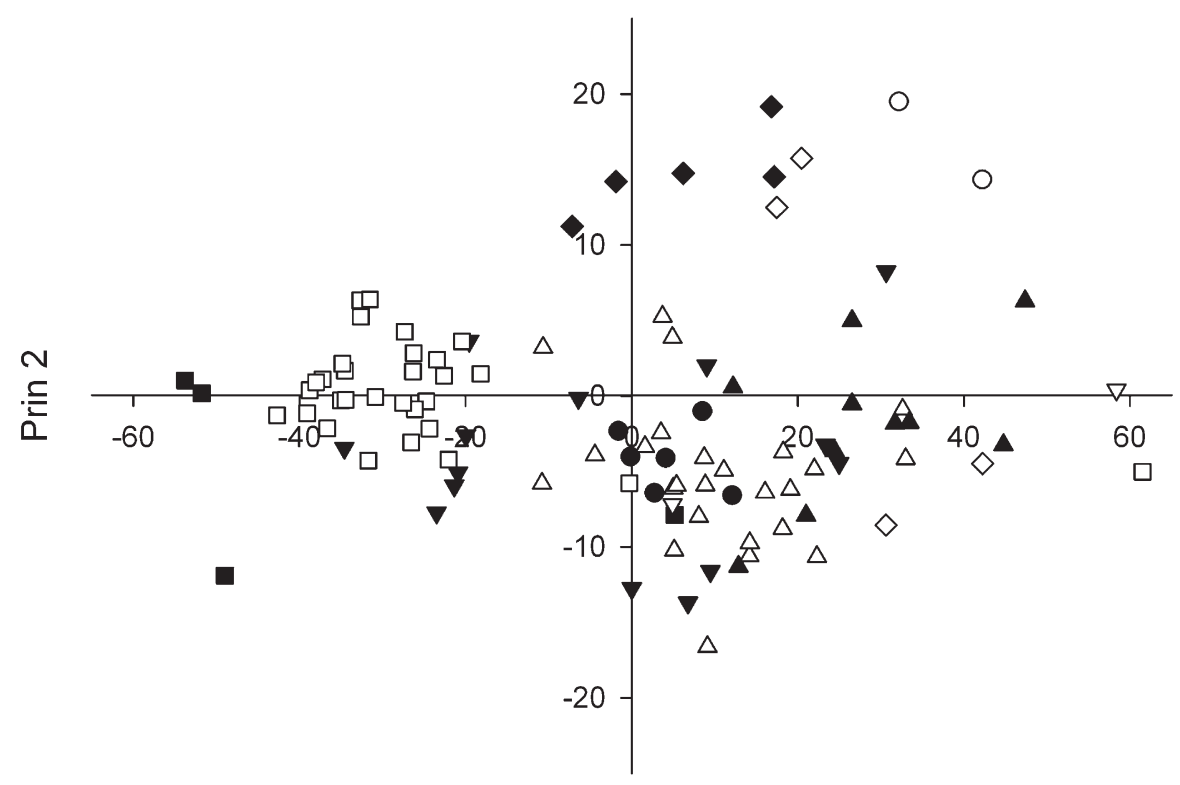

Prin 1

\begin{tabular}{|ll|}
\hline$\bullet$ & BVMG \\
$\bigcirc$ & Common \\
$\nabla$ & Compact \\
$\Delta$ & Compact America \\
$\square$ & High Density \\
$\square$ & Compact Midnight \\
$\bullet$ & Julia \\
$\diamond$ & Mid-Atlantic \\
$\boldsymbol{\Delta}$ & Shamrock \\
$\nabla$ & Texas \\
\hline
\end{tabular}

Fig. 2. Principal component analysis (PCA) of Kentucky bluegrass cultivars and selections based on morphological characteristics in 2005. PC1 accounted for $73.3 \%$ of the variation and was strongly influenced by rhizome spread. PC2 accounted for $21.6 \%$ of the variation and was strongly influenced by plant height.

expected from a cultivar with aggressive spreading capabilities. Because of these contradictory results, this group has been renamed the High Density type (Shortell et al., 2006) because they may not exhibit aggressive spreading characteristics in all environments.

High broad-sense heritability estimates were observed for rhizome spread measurements (Table 3), which supports previous data collected on rhizome spread in Kentucky bluegrass (Berry et al., 1969; Pepin and Funk, 1974) and sand bluestem (Andropogon hallii Hack.) (Kneebone, 1958). However, selection for this trait when grown as a spaced plant is not necessarily correlated to aggressive lateral rhizome spread when maintained under frequently mowed (Brosnan et al., 2005) or worn turf conditions (Park et al., 2005).
There were no significant differences between Kentucky bluegrass classification types for flag leaf length or width, indicating that these measurements were not useful in differentiating the classification types. Additionally, flag leaf length was moderately heritable $(\mathrm{H}=0.71)$ and flag leaf width was not heritable $(\mathrm{H}=0.11)$ (data not shown). These results indicate that selection for fine or wide leaf texture may be difficult and that the phenotype may not be the same across environments. This agrees with the data reported by Simon (1999) on wheat (Triticum aestivum L.). However, earlier research on Kentucky bluegrass (Berry et al., 1969), perennial ryegrass (Lolium perenne L.) (Rogers, 1989), and bermudagrass (Cynodon dactylon [L.] Pers.) (Wofford and Baltensperger, 1985) has shown this trait to be more heritable.
Not surprisingly, leaf texture (or leaf width) has been shown to be correlated with plant and/or tiller density (Turgeon, 1999). Thereby, plants that have a high tiller density also have finer leaves and plants with low tiller density have wider leaves (Nilsen and Orcutt, 1996). This can be partially attributed to the space available for the plants to grow within the turfgrass community. If plants are not competing for space, leaves have the opportunity to elongate and widen to maximize photosynthesis (Nilsen and Orcutt, 1996). Additionally, as plants mature, flowering culms begin to desiccate and flag leaves start to senesce. As a result of the considerable number of plants to measure and a short timeframe for collecting these data in the field flag leaf width measurements may have been partly influenced by plant desiccation. Flag leaf width is a standard measurement required for PVP applications. Claims are often made regarding variety performance compared with other cultivars. The low heritability of this trait indicates that the flag leaf width measurement may not be as reproducible as once perceived.

Principal component analysis is used to take a large number of variables and convert them into a smaller number of informative factors that account for more variation then any one variable alone. These factors, or principal components, can then be visualized to determine whether any correlations exist Principal components are created through matrix algebra using SAS. The residuals from a least squares estimation of the morphological parameters are used to construct a matrix. Principal components 1 to 6 are generated through a singular value decomposition of this matrix (Saxton, 2004). The resulting components are then ordered and the variation can be graphed.

Principal Component 1 (PC1) and Principal Component 2 (PC2) in 2004 accounted for $68.7 \%$ and $22.5 \%$ of the variation, respectively, or $91.2 \%$ of the total variation (Table 4). Principal Component 3 ( $\mathrm{PC} 3$ ) raised the total variation to $95.6 \%$ but did not change the overall pattern of the graph and therefore is not presented. PC1 and PC2 in 2005 accounted for $73.3 \%$ and $21.6 \%$ of the variation, respectively, or $94.9 \%$ of the total variation (Table 4). PC3 raised the total variation to $99.8 \%$ but did not change the overall pattern and therefore is not presented. Rhizome spread had the strongest influence on PC1 and plant height had the strongest influence on PC2 in both 2004 and 2005. Certain cultivars and selections formed distinct clusters, including the Common, Shamrock, Compact-America, Compact-Midnight, and BVMG types in both 2004 and 2005 (Figs. 1 and 2). However, Compact-America types were more widely dispersed than the other groups in 2005 .

Compact-America and Compact-Midnight cultivars did segregate, but the general Compact type was dispersed across both Compact-Midnight and Compact-America types. Mid-Atlantic, Texas $\times$ Kentucky bluegrass hybrids, and to some degree the Shamrock types were morphologically similar based on 
Table 3. Analysis of variance and broad-sense heritability estimates (H) of plant height, panicle length, flag leaf height, and rhizome spread of 173 Kentucky bluegrass cultivars and selections (includes all entries of the 2000 National Kentucky bluegrass test sponsored by the National Turfgrass Evaluation Program) evaluated in 2004 and 2005 in a spaced-plant nursery established in Adelphia, NJ, in 2003.

\begin{tabular}{|c|c|c|c|c|c|c|c|c|}
\hline & \multicolumn{4}{|c|}{ Plant ht } & \multicolumn{4}{|c|}{ Panicle length } \\
\hline & MS & $\mathrm{F}$ value & $P$ value & Var. comp. ${ }^{z}$ & MS & F value & $P$ value & Var. comp. \\
\hline Year & $71,674.9$ & $1,242.7$ & 0.0008 & & 58.5 & 67.8 & 0.0144 & \\
\hline $\operatorname{Rep}^{y}$ & $6,211.1$ & 107.7 & $<0.0001$ & & 1.9 & 2.2 & 0.1162 & \\
\hline Year $\times$ rep & 906.6 & 15.7 & $<0.0001$ & & 14.3 & 16.5 & $<0.0001$ & \\
\hline Cult $^{\mathrm{x}}$ & $1,274.1$ & 22.1 & $<0.0001$ & 177.4 & 27.7 & 32.2 & $<0.0001$ & 4.1 \\
\hline Cult $\times$ year & 209.8 & 3.6 & $<0.0001$ & 19.1 & 3.3 & 3.8 & $<0.0001$ & 0.2 \\
\hline \multirow[t]{3}{*}{ Cult $\times$ rep $\times$ year } & 95.1 & & & 15.9 & 2.0 & & & 0.3 \\
\hline & \multicolumn{4}{|c|}{$\begin{array}{c}\mathrm{H}=0.835^{\mathrm{w}} 95 \% \text { confidence interval for three-replicate } \\
\text { mean heritability }=0.88-0.79\end{array}$} & \multicolumn{4}{|c|}{$\begin{array}{c}\mathrm{H}=0.88195 \% \text { confidence interval for three-replicate } \\
\text { mean heritability }=0.93-0.84\end{array}$} \\
\hline & \multicolumn{4}{|c|}{ Flag leaf ht } & \multicolumn{4}{|c|}{ Rhizome spread } \\
\hline Year & $43,923.7$ & $2,585.2$ & 0.0004 & & $1,507,579.2$ & $14,682.0$ & 0.0001 & \\
\hline Rep & 389.1 & 22.9 & $<0.0001$ & & $4,787.8$ & 46.6 & $<0.0001$ & \\
\hline Year $\times$ rep & 545.2 & 32.1 & $<0.0001$ & & $1,899.5$ & 18.5 & $<0.0001$ & \\
\hline Cult & 517.5 & 30.5 & $<0.0001$ & 72.9 & $4,588.4$ & 44.7 & $<0.0001$ & 687.2 \\
\hline Cult $\times$ year & 79.9 & 4.7 & $<0.0001$ & 6.7 & 465.1 & 4.5 & $<0.0001$ & 34.9 \\
\hline \multirow[t]{2}{*}{ Cult $\times$ rep $\times$ year } & 39.6 & & & 6.6 & 255.4 & & & 42.6 \\
\hline & \multicolumn{4}{|c|}{$\begin{array}{c}\mathrm{H}=0.84695 \% \text { confidence interval for three-replicate } \\
\text { mean heritability }=0.89-0.80\end{array}$} & \multicolumn{4}{|c|}{$\begin{array}{c}\mathrm{H}=0.84695 \% \text { confidence interval for three-replicate } \\
\text { mean heritability }=0.88-0.79\end{array}$} \\
\hline
\end{tabular}

${ }^{z}$ Variance components were determined using restricted maximum likelihood estimation using the random model of Proc Mixed Procedure in SAS (Cary, NC). ${ }^{\mathrm{y}} \mathrm{Rep}=$ replication.

${ }^{\mathrm{x}}$ Cult = cultivar.

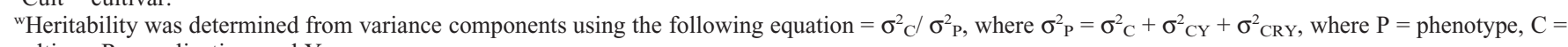
cultivar, $\mathrm{R}=$ replication, and $\mathrm{Y}=$ year.

Table 4. Eigenvectors of the principal component axes (PC) from principal component analysis of Kentucky bluegrass types. ${ }^{\mathrm{z}}$

\begin{tabular}{|c|c|c|c|c|c|c|c|c|c|c|c|c|}
\hline & \multicolumn{2}{|c|}{$\mathrm{PC} 1$} & \multicolumn{2}{|c|}{ PC2 } & \multicolumn{2}{|c|}{ PC3 } & \multicolumn{2}{|c|}{ PC4 } & \multicolumn{2}{|c|}{ PC5 } & \multicolumn{2}{|c|}{ PC6 } \\
\hline & 2004 & 2005 & 2004 & 2005 & 2004 & 2005 & 2004 & 2005 & 2004 & 2005 & 2004 & 2005 \\
\hline Character & --------- & & 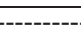 & ------ & 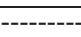 & --- Eige & ectors - & -------- & --------- & -------- & ------- & ------- \\
\hline Plant height & 0.41 & 0.27 & 0.70 & 0.92 & -0.58 & -0.30 & 0.04 & -0.01 & -0.05 & 0.00 & 0.00 & 0.00 \\
\hline Panicle length & 0.04 & 0.03 & 0.08 & 0.02 & 0.06 & 0.06 & 0.21 & 0.80 & 0.97 & -0.60 & -0.01 & -0.01 \\
\hline $\begin{array}{l}\text { Flag leaf } \\
\text { height }\end{array}$ & 0.21 & 0.12 & 0.54 & 0.27 & 0.81 & 0.95 & -0.10 & -0.06 & -0.08 & 0.04 & 0.00 & 0.00 \\
\hline $\begin{array}{c}\text { Flag leaf } \\
\text { length }\end{array}$ & 0.00 & 0.00 & 0.01 & 0.00 & 0.09 & 0.00 & 0.97 & 0.60 & -0.21 & 0.80 & -0.03 & -0.01 \\
\hline $\begin{array}{l}\text { Flag leaf } \\
\text { width }\end{array}$ & 0.00 & 0.00 & 0.00 & 0.00 & 0.00 & 0.00 & 0.03 & 0.02 & 0.01 & 0.00 & 1.00 & 1.00 \\
\hline Rhizome spread & 0.89 & 0.95 & -0.46 & -0.30 & 0.08 & -0.03 & 0.00 & -0.02 & -0.01 & 0.01 & 0.00 & 0.00 \\
\hline Eigenvalue & 249.98 & 553.14 & 81.72 & 162.95 & 16.08 & 36.73 & 14.97 & 1.40 & 0.90 & 0.44 & 0.00 & 0.00 \\
\hline $\begin{array}{l}\text { Percentage of total } \\
\text { variation }\end{array}$ & 68.7 & 73.3 & 91.2 & 94.9 & 95.6 & 99.8 & 99.8 & 99.9 & 100.0 & 100.0 & 100.0 & 100.0 \\
\hline
\end{tabular}

${ }^{\mathrm{z} E i g e n v a l u e s}$ and their contribution to total variation are listed at the bottom of columns.

the traits studied in this experiment. This could be the result of the high correlation of PC1 to rhizome spread measurements. Julia types tended to weakly cluster within the Compact type grouping in 2004 (Fig. 1).

Similar clustering results were reported by Curley and Jung (2004) who evaluated a set of random amplified polymorphic DNA markers among Kentucky bluegrass cultivars and selections. They also found that CompactMidnight type cultivars formed a distinct cluster separate from the other types evaluated in their study (Curley and Jung, 2004). In our study, Compact-Midnight types also formed a tight cluster, but it was within the general Compact type. Curley and Jung's genetic analysis with molecular markers also agrees with our morphological classification of the Common and BVMG types. This concordance between morphological and molecular-based analysis helps support the Kentucky bluegrass classification system, and further work using a combined approach could help add cultivars and selections from the Other type into more defined groups. This combination of approaches could also help clarify existing classification groups and help discover new groups with unique traits and uses.

\section{Conclusions}

We found significant differences in morphological and agronomic traits between the classification types of Kentucky bluegrass, which is consistent with previous research. However, unlike previous studies, which are now outdated, this project reports on new, recently developed Kentucky bluegrass cultivars. High Density, BVMG, and Compact (including Compact-Midnight and CompactAmerica) type cultivars have the shortest plant heights. Mid-Atlantic, Texas $\times$ Kentucky bluegrass hybrids, and Common type cultivars exhibited the most extensive rhizome spread. Principal component analysis grouped Compact-Midnight and CompactAmerica types as clusters within the general
Compact type. Common types were consistently grouped separately from the other groups, whereas Mid-Atlantic, Texas $\times$ Kentucky bluegrass, and to some extent Shamrock types were grouped in close proximity to each other indicating that these groups have similar morphological characteristics. Principal component analysis results based on morphological measurements were similar to results based on molecular markers indicating that the similarity between groups is consistent with both marker types and should both be useful to help classify Kentucky bluegrass further.

Based on the data reported here, it should be possible to select Kentucky bluegrass genotypes with certain morphological and agronomic traits, including plant height, rhizome spread, panicle height, flag leaf height, and length that behave consistently across environments. This information will help breeders be more successful in developing cultivars with important morphological and agronomic characteristics. It will also be 
useful to turfgrass managers in selecting blends of Kentucky bluegrass cultivars with complementary characteristics.

\section{Literature Cited}

Bara, R.F., W.K. Dickson, J.A. Murphy, D.A. Smith, and C.R. Funk. 1993. Performance of Kentucky bluegrass cultivars and selections in New Jersey turf trials. Rutgers Turfgrass Proc. 25:49-94.

Bashaw, E.C. and C.R. Funk. 1987. Apomictic grasses, p. 40-82. In: Fehr W.R. (ed.). Principles of cultivar development. Vol. 2. Crop species. Macmillan, New York, NY.

Berry, C.D., D.V. Glover, and W.H. Daniel. 1969. Phenotypic and genotypic variation and covariation of some quantitative turf characteristics in Poa pratensis L. Crop Sci. 9:470-473.

Bicknell, R.A. and A.M. Koltunow. 2004. Understanding apomixis: Recent advances and remaining conundrums. Plant Cell 16:S228-S245.

Bonos, S.A. 2007. Commercially available coolseason turfgrass species and cultivar resource list. Rutgers Turfgrass Proc. 38:159-178.

Bonos, S.A., M.D. Casler, and W.A. Meyer. 2003. Inheritance of dollar spot resistance in creeping bentgrass. Crop Sci. 43:2189-2196.

Bonos, S.A., C. Kubik, B.B. Clarke, and W.A. Meyer. 2004. Breeding perennial ryegrass for resistance to gray leaf spot. Crop Sci. 44:575580.

Bonos, S.A., W.A. Meyer, and J.A. Murphy. 2000. Classification of Kentucky bluegrass genotypes grown as spaced-plants. HortScience 35:910 913.

Bonos, S.A. and J.A. Murphy. 1999. Growth responses and performance of Kentucky bluegrass under summer stress. Crop Sci. 39:770-774.

Brosnan, J.T., J.S. Ebdon, and W.M. Dest. 2005. Characteristics in diverse wear tolerant genotypes of Kentucky bluegrass. Crop Sci. 45:1917-1926.

Burt, M.G. and N.E. Christians. 1990. Morphological and growth characteristics of low and highmaintenance Kentucky bluegrass cultivars. Crop Sci. 30:1239-1243.
Burton, G.W. and E.H. DeVane. 1953. Estimating heritability in tall fescue (Festuca arundinacea) from replicated clonal material. Agron. J. 45:478-481.

Curley, J. and G. Jung. 2004. RAPD-based genetic relationships in Kentucky bluegrass: Comparison of cultivars, interspecific hybrids, and plant introductions. Crop Sci. 44:1299-1306.

Ebdon, J.S., A.M. Petrovic, and S.J. Schwager. 1998. Evaluation of discriminate analysis in identification of low- and high-use Kentucky bluegrass cultivars. Crop Sci. 38:152-157.

Funk, C.R. 2000. Long live Kentucky bluegrass, the king of the grasses. Diversity 16:26-28.

Kneebone, W.R. 1958. Heritabilities in sand bluestem (Andopogon hallii Hack.) as estimated from parental clones and their open-pollination progenies. Agron. J. 50:459-461.

Meyer, W.A. and C.R. Funk. 1989. Progress and benefits to humanity from breeding cool-season grasses for turf, p. 31-48. In: sleper, D.A., K.H Asay, and J.F. Pederson (eds.). Contributions from breeding forage and turf grasses. CSSA Spec. Publ. 15. Crop Sci. Soc. of Amer., Madison, WI.

Morris, K.N. 2000. National Turfgrass Evaluation Program (NTEP). 2000 national Kentucky bluegrass test. USDA, Beltsville, MD.

Murphy, J.A., S.A. Bonos, and P. Perdomo. 1997. Classification of Poa pratensis genotypes. Intl. Turfgrass Soc. Res. J. 8:1176-1183.

Nilsen, E.T. and D.M. Orcutt. 1996. The physiology of plants under stress: Abiotic factors. John Wiley and Sons, Inc., New York, NY. p. 72-163.

Nyquist, W. 1991. Estimation of heritability and prediction of selection response in plant populations. Crit. Rev. Plant Sci. 10:235-322.

Park, B.S., J.A. Murphy, W.A. Meyer, S.A. Bonos, J. den Haan, D.A. Smith, and T.J. Lawson. 2005. Performance of Kentucky bluegrass within phenotypic classifications as affected by traffic. International Turfgrass Society Research Journal 10:618-625.

Pepin, G.W. and C.R. Funk. 1974. Evaluation of turf, reproductive, and disease-response characteristics in crossed and selfed progenies of Kentucky bluegrass. Crop Sci. 14:356-359.
Poehlman, J.M. and D.A. Sleper. 1995. Breeding field crops, p. 71-75. Iowa State University Press, Ames, IA.

Rogers, M.E. 1989. Variation in turf-type morphological characteristics within Lolium perenne L. cv. Victorian. Aust. J. Agr. Res. 40:851-859.

SAS Institute. 2001. SAS/STAT user's guide, Release V8. SAS Institute, Cary, NC.

Saxton, A.M. 2004. Genetic analysis of complex traits using SAS, p. 76. SAS Institute Inc., Cary, NC.

Shortell, R.R., W.K. Dickson, B.S. Park, R.F. Bara, D.A. Smith, M.M. Wilson, T.J. Lawson, J Clark, S.A. Bonos, J.A. Murphy, C.R. Funk, and W.A. Meyer. 2005. Performance of Kentucky bluegrass cultivars and selections in New Jersey turf trials. 2004 Rutgers Turfgrass Proceedings. 36:49-118.

Shortell, R.R., W.A. Meyer, and S.A. Bonos. 2006 Morphological characteristics of Kentucky bluegrass cultivars and selections grown in New Jersey. 2005 Rutgers Turfgrass Proc. 37: 183-192.

Simon, M.R. 1999. Inheritance of flag-leaf angle, flag-leaf area and flag-leaf area duration in four wheat crosses. Theor. Appl. Genet. 98:310314.

Soleri, D. and S.E. Smith. 2002. Rapid estimation of broad sense heritability of farmer-managed maize populations in the central valleys of Oaxaca, Mexico, and implications for improvement. Euphytica 128:105-119.

Steel, R.G.D., J.H. Torrie, and D.A. Dickey. 1997. Principles and procedures of statistics a biometrical approach, p. 59-61. McGraw Hill Inc., New York, NY.

Turgeon, A.J. 1999. Turfgrass management, p. 227-301. 5th Ed Prentice Hall, Upper Saddle River, NJ.

USDA. 2005. Plant variety protection act and regulations and rules of practice. Plant Variety Protection Office, Beltsville, MD.

Wofford, D.S. and A.A. Baltensperger. 1985. Heritability estimates for turfgrass characteristics in bermudagrass. Crop Sci. 25:133136. 